\title{
US-China Trade War and Its Implications on the Global Economy
}

Author(s): Dukgeun Ahn, Jun Yeop Lee

Source: Journal of International Logistics and Trade 2021; 19(4):181-184

Published by: Jungseok Research Institute of International Logistics and Trade, Inha University

DOI: https://doi.org/10.24006/jilt.2021.19.4.181

Journal of International Logistics and Trade is an official journal published by Jungseok Research Institute of International Logistics and Trade, Inha University, Korea. JILT welcomes manuscripts that advance the practice and science of logistics, trade, and other related fields.

Frequency: Quarterly (March, June, September, December)

Stable URL: https://www.ejilt.org

Jungseok Research Institute of International Logistics and Trade is a specialized academic research institute representing Inha University and Inha Foundation in Korea. The institute aims to become a representative institute in Northeast Asia in the research of logistics and trade.

Stable URL: https://jrieng.inha.ac.kr

(C) Copyright. Jungseok Research Institute of International Logistics and Trade.

This is an Open-Access article distributed under the terms of the Creative Commons Attribution NonCommercial License (http://creativecommons.org/licenses/by-nc/4.0/) which permits unrestricted noncommercial use, distribution, and reproduction in any medium, provided the original work is properly cited 

${ }^{1}$ Graduate School of International Studies, Seoul National University, Seoul, Korea

${ }^{2}$ Department of International Trade and Regional Studies, Inha University, Incheon, Korea

\author{
Received December 09, 2021 \\ Revised December 15, 2021 \\ Accepted December 17, 2021 \\ *Corresponding author: Dukgeun Ahn \\ Graduate School of International Studies, \\ Seoul National University, Seoul, Korea \\ Tel: $+82-2-880-9249$ \\ Fax: +82-2-879-1496 \\ E-mail: dahn@snu.ac.kr
}

\begin{abstract}
This editorial proposes three fundamental issues in the international economic field evoked by the US-China trade war. The first is the intensifying conflict between protectionism measures and the coherence with relevant global trade rules. The second is decoupling between the US and China and subsequent evolution in the global production network. The third is the digression in the trade flow between the US and China and the resulting change in innovative capabilities and manufacturing competitiveness among major industrial countries. This editorial also offers the long-term perspective of the current global trade war and how the world encounters repercussion of openness and protectionism as well as times of prosperity and uncertainty.
\end{abstract}

Keywords US and China trade war, Protectionism, Global production network, Industrial competitiveness

\section{Introduction}

In Wealth of Nations, Adam Smith argued that an open market and free trade are, in principle, beneficial to the economy. Hence, the economic growth of nations is fundamentally determined by specialization, international trade, the division of labor, and eventually, productivity improvement. The economic miracle since the early 1960s of Asia's four little dragons (Balassa 1978; Chow 1989) and China's remarkable rise since its opening up and reform policies in 1978 (Herrerias and Orts 2010; Liu et al. 2019; Shan and Sun 2010) have also been mainly due to active participation in the international markets, productivity improvement, and accompanying industrial development.

In the same context, as Richard Baldwin coined it, from 1990 to the early 2010s, the global economy experienced the era of Great Convergence with the development of ICT, the transfer of production facilities from advanced countries, and offshoring of production to a handful of developing countries primarily located in Asia (Baldwin 2016). Furthermore, China's accession to the WTO in 2001 triggered strengthening of the global division of production and the Great Convergence.

After the Obama administration changed a broad range of policies towards China, the Trump administration triggered the US-China trade war. That provoked serious competition and conflicts in various fields, such as industry, finance, technology, and global hegemony. Concerns about supply chains that rely excessively on China have also led to reshoring of production facilities to other advanced countries. Aside from its causes, the US-China trade war has fundamentally reshaped global value chains and industry cooperation systems in the world economy, which raises unprecedented challenges on the future's path for the global trading system. Substantial reduction of production costs incurred by production automation made reshoring to developed countries possible. In addition, the COVID-19 pandemic has rapidly dampened international cooperation and global supply chain networks. With all these natural and unnatural disasters, global trade has deviated from the past conventional path and has encountered opposite trends in regionalization or segregation of supply chain systems.

\section{US-China trade war implications for international logistics and trade}

In November 2020, the Board of JILT launched the editorial committee for this special issue. Considering the various aspects of the US-China trade war, it was a very difficult task to select areas to focus on for this special issue. Even though there are multiple aspects to the US-China trade war, the core issues for international logistics and trade ultimately turned out to be production relocation and division of labor between countries. Therefore, we agreed to focus on changes in production 
competitiveness and supply chain networks in each country. More specifically, focusing on the following three areas would contribute to current and future research.

First, this special issue focuses on legal issues in the newly evolving trade system. Because the US-China trade war began with retaliatory tariffs, it is necessary to consider protectionism and the related trade regulations. Protectionist trade measures have crucially affected the global production network. Many countries have already modified trade regulations that were adopted to build global production networks, such as a favorable corporate tax and subsidy systems for overseas production. For example, the US and the European Union (EU) have implemented discriminatory policies against other countries with regard to the environment, national security, safe supply chains, and corporate governance. Therefore, it is important to review whether such newly introduced trade measures conform to WTO legal structures.

From a long-term historical point of view, the pendulum of trade policies has moved from free trade to protectionism. A paradigm shift in trade policies has widespread ripple effects on production and economic growth. With abolition of the Corn Law in 1848, the era of free trade flourished, which led the United Kingdom (UK) to establish the British Empire which, at the same time, led to global economic growth. On the other hand, after World War I, along with dissolution of the gold standard, countries indulged in protectionism primarily to manipulate exchange rates. The 1930 Smoot-Hawley bill in the United States aggravated protectionism and brought about not just changes in production networks but a global recession. After World War II, the Bretton Woods system, GATT, and the subsequent WTO restored global economies.

With the trigger of the US-China trade dispute, the global economy faces transition to a protectionism era again. The Biden administration strengthened its protectionist stance by establishing strategic alliances with key partners, including the EU, Japan, the UK, and Australia. It aims to form economic blocs exclusively linking the allies and democratic countries. In response, China promoted the dual circulation strategy focusing on ingenious innovation, domestic markets, and local trade. In fact, a 2020 WTO empirical analysis showed that negative effects from the increase in policy uncertainty, and the resulting reduction in exports and investment due to the trade war between the two countries, are quite substantial.

Second, this issue examines the global production network. If the US-China trade war continues to escalate and, consequently, supply chains for critical items such as semiconductors dissolve into regional networks, the global trading system will have to deal with fundamental changes in international logistics. The recent shortage of semiconductors and medical supplies has raised concerns about the global production networks in all countries. According to AT Kearney (2020), its US Reshoring Index hit an all-time high in 2019, implying escalating decoupling trends between the US and China. Anukoonwattaka et al. (2020) compiled value-added trade data from 62 countries by using ADB's Multi-Regional Input-Output database. According to their research, the global value chain has diversified and, paradoxically, a strengthening of supply chains with third countries was observed as the US-China trade war reduced their dependence on each other. The COVID-19 pandemic significantly changed supply chains and the international division of labor. However, there are still conflicting claims that decoupling between the US and China is unlikely to occur, or is even impossible. Farrell and Newman (2020) argued that countries worldwide are closely integrated into complex networks for trade, finance, and information, among other fields. It is challenging to accurately identify links among them and to exert fine-tuned decoupling policies. Third, this special issue attempts to introduce new research on industrial competitiveness, assuming that the US-China trade war has a profound negative impact on the global supply chain. Each country must eventually establish an independent industrial structure, which will significantly affect each country's technology and industrial competitiveness. China has maintained the highest growth in manufacturing competitiveness over the past decade. Such manufacturing competitiveness is primarily due to Chinese domestic companies that enhanced their competitiveness in overseas markets and is due to multinational companies that have actively cooperated with Chinese firms. However, since the early days of the trade dispute, the US ban on technology utilization and semiconductor supplies to major Chinese companies such as Huawei has profoundly damaged China's technology and manufacturing competitiveness. In response, China has been trying to build an independent manufacturing ecosystem by investing massively in strategic industries such as semiconductors. It is very likely that trade and technology disputes between the two countries will continue to intensify. Therefore, the US-China trade dispute is a battle for future leadership in technology and industry (Schneider-Petsinger et al. 2019). According to Boston Consulting Group (2019), if technology competition and trade competition proceed simultaneously, the US-China trade dispute will likely develop into a technology cold war. In other words, if the US strengthens non-tariff barriers against China in the high-tech sector, China could ban exports of vital raw materials to the US and fortify anti-trust measures against US tech companies. 


\section{Key findings in the special issue}

The first paper, by Hong et al. (2021) and titled WTO's Special and Differentiated Treatment (S\&DT) Principle and Solutions of the US-China Conflict, examines S\&DT (which played a decisive role in revitalizing the development process of the WTO) and the participation of developing countries in the process. The authors also explained the process of neutralizing the WTO system, paradoxically causing conflict with China in the US-China trade dispute. In other words, in competition with China, the US implements new trade blocs, such as the US-Mexico-Canada Agreement (USMCA), to decouple China from the world supply chain. According to the authors' logic, China needs to recover and return to the WTO system rather than engage in bilateral negotiations with the United States. A critical obstacle here is China's non-market economy. As the authors argue, the most advantageous way for China, in the long run, is recovery of the WTO system through concessions via S\&DT. Therefore, China needs to continue its corresponding market and economic reforms to eliminate obstacles to its return to the WTO.

The second paper, by You et al. (2021), is titled US-China Competition from a Perspective of Global Product Network: Trends and Implications of Industrial Competitiveness Between Countries Using Product Space Model. In this paper, using the product space model, the authors examine the trend in industrial competition between the US and China, which is the most crucial determinant in future development of the global economy. Faced with decoupling of the supply chain caused by the USChina trade war, industrial competitiveness is critical in predicting the future industrial competitiveness of these countries. In particular, in the case of China, the most fundamental problem with the US supply chain decoupling policy is how to sustain indigenous innovation and industrial development. In using a product space model methodology, the EXPY_C trend, which demonstrates current industrial competitiveness, appears to give a comparative advantage to low-tech industries in China. On the other hand, according to a density index that evaluates future industrial competitiveness, China has a greater possibility of developing high-tech sectors than other countries. However, the product space model is an inter-product network model in which countries actively participate in world trade and demonstrate a high revealed comparative advantage (RCA) in their comparative-advantage sectors. The prerequisite for China's competitiveness in high-tech industries is active participation in world trade. Therefore, despite the US-China trade war, the most crucial factor for China's long-term industrial development is substantial participation in world trade.

The third paper, by Kim et al. (2021) and titled Has the US-China Trade War Caused Trade Decoupling?, analyzes the production network changes caused by the US-China trade war. The authors attempt to verify the presence of trade decoupling between the US and China through a network analysis primarily focusing on HS six-digit codes for final goods and intermediate goods needed to produce mobile phones. The main contribution of the paper is suggesting a framework for trade network decoupling using the production function of non-competitive input-output tables, network analysis, and scenario analysis. Visual analysis through a multi-dimensional scaling (MDS) technique and centrality analysis both show significant changes in the network structure between 2017 and 2019, a weakening centrality in China, and a strengthening centrality in Vietnam. The paper uses scenario analysis of the escalating trade war, from scenario 1 to scenario 3, based on China's out-degree centrality, East Asian countries' out-degree centrality, and global connectivity decreases. This result implies the US-China trade war will create a lose-lose game, and the world production network will change from US-China domination to a more diversified production network.

The fourth paper, by Lee (2021) and titled Changing Paradigms in US and EU Supply Chains: Focusing on Sustainability Issues, examines the changing paradigm in US and EU supply chains, focusing on sustainability issues. In this paper, the authors explain the US supply chain resilience, and the policy to promote industrial competitiveness. And the authors review the EU's response to the challenges posed by China and the US from unilateral trade policies under the Trump administration. The EU has pursued policies of strategic autonomy, sustainable corporate governance, and supply chain resilience. The authors' crucial contribution is analyzing the conformity issues between these policies and WTO rules, such as non-discrimination, subsidies, general exceptions for legitimate policies, and national security exceptions. The authors argue that the future direction of the world economic order seems to be undergoing a paradigm shift trying to incorporate sustainability under the trade umbrella. In this process, these efforts will either work for the international economy or the global economy will be more starkly divided into regional blocs with higher entry barriers into the markets of developed country.

\section{Concluding remarks}

We hope the papers in this special issue shed some light on the research in international logistics and trade concerning the US-China trade war. Until these two leading trading nations find a solution to the continuously aggravating economic war, we 
will face more new issues to scrutinize with rigorous analysis and debate.

\section{References}

Anukoonwattaka, W., Romao, P., Lobo, R. S., 2020. If the US-China trade war is here to stay, what are the risks and opportunities for other GVC economies outside the war zone? UN-ESCAP Working Paper 209.

AT Kearney, 2020. Global pandemic roils 2020 reshoring index, shifting focus from reshoring to right-shoring. Available at: https://www.kearney.com/operations-performance-transformation/us-reshoring-index

Balassa, B., 1978. Exports and economic growth: Further evidence. Journal of Development Economics 5, 181-189.

Baldwin, R., 2016. The Great Convergence: Information Technology and the New Globalization. Belknap Press of Harvard University Press, Cambridge, MA.

Bekkers, E., Schroeter, S., 2020. An economic analysis of the US-China trade conflict. WTO Staff Working Paper No. ERSD2020-04.

Boston Consulting Group, 2019. Unpacking the US-China tech trade war. Available at. https://www.bcg.com/publiccations/2019/us-china-tech-trade-war

Chow, P. C. Y., 1989. Causality between export growth and industrial development: Empirical evidence from the NICs. Journal of Development Economics 31, 416-417.

Edwards, S., 1993. Openness, trade liberilazation, and growth in developing countries. Journal of Economic Literature 31 , 1358-1393.

Farrell, H., Newman, N., 2020. Will the Coronavirus end globalization as we know it? Foreign affairs. Available at: https://www.foreignaffairs.com/articles/2020-03-16/will-coronavirus-end-globalization-we-know-it

Herrerias, M. J., Orts, V., 2010. Is the export-led growth hypothesis enough to account for China's growth? China \& World Economy 18, 34-51.

Hong, K., Yoo, J. H., Cheong, I., 2021. WTO’s special and differentiated treatment (S\&DT) principle and solutions of the USChina conflict. Journal of International Logistics and Trade 19(4), 185-196.

Kim, J., Lee, J., Kim, B., 2021. Has the US-China trade war caused trade decoupling?. Journal of International Logistics and Trade 19(4), 211-222.

Lee, H., 2021. Changing paradigms in US and EU supply chains: focusing on sustainability issues. Journal of International Logistics and Trade 19(4), 223-236.

Liu, M. H., Margaritis, D., Zhang, Y., 2019. The global financial crisis and the export-led economic growth in China. The Chinese Economy 52, 232-248.

Schneider-Petsinger, M., Wang, J., Jie, Y., Crabtree J., 2019. US-China strategic competition: The quest for global technological leadership. Chatam House. Available at: https://www.chathamhouse.org/2019/11/us-china-strategic-competition

Shan, J., Sun, F., 2010. On the export-led growth hypothesis: The econometric evidence from China. Applied Economics 30, 1055-1065.

Yoo, J., Lee, J., Kim, H. J., 2021. US-China competition from a perspective of global product network: trends and implications of industrial competitiveness between countries using product space model. Journal of International Logistics and Trade 19(4), 197-210. 